in the National Gallery, the subject is depicted seated. Newton himself presented a portrait in 1717, by Charles Jervas, sometime a pupil of Kneller. [For the third portrait see below, Martin Folkes.]

Sir Hans Sloane (1727-41). (Sir Godfrey KnellerSir Hans Sloane, 1716, after the close of his secretaryship.)

Martin Folkes (1741-52). In addition to his own portrait, Folkes gave the Society a choice portrait of Francis Bacon; also one of Newton, signed by Vanderbank. Folkes was also finely delineated by Thomas Hudson, almost whole-length, seated in the presidential chair, the mace in the picture. This portrait is not at the Royal Society. (William Hogarth-president.)

Earl of Macclesfield (1752-64). (Thomas Hudsonpresident.)

Earl of Morton (1764 to Oct. 12, 1768). No portrait.

Sir James Burrow (Oct. 27, 1768, to Nov. 30, 1768, and July 2, 1772-Nov. 30, 1772). This fine portrait shows him three-quarters length, in velvet surtout, with neckcloth, seated near a table, on which the left arm is resting. (J. B. Van Loo-president.)

James West (1768-July 2, 1772). No portrait.

Sir John Pringle (1772-78) ; the "Father of Military Hygiene ". (Sir Joshua Reynolds-president.)

Sir Joseph Banks (1778-June 19, 1820). Almost whole-length, seated in the presidential chair, in full panoply of the insignia of the Order of the Bath, with the mace and a silver-gilt inkstand, showing upright quills. Probably the portrait of him in the British Museum, by Sir Thomas Lawrence, would receive preference, where the accessories are not so oppressively obvious in the scheme. (Thomas Phillipsexecutors of Don José de Mendoza Rios.)

W. H. Wollaston (June 29, 1820-Nov. 30, 1820); one of the seventeen children of a clergyman. ( $\mathrm{J}$. Jackson-president's family.)

Sir Humphry Davy (1820-27) ; almost whole-length, standing, facing spectator. (Sir Thomas LawrenceLady Davy, in 1829.)

Davies Gilbert (1827-30). (Thomas Phillipspresident.)

H.R.H. the Duke of Sussex (1830-38). During his tenure of office he constantly presided at meetings of the Council and Society. (Thomas Phillips-president.)
Marquess of Northampton (1838-48). (Thomas Phillips-president.)

Earl of Rosse (1848-54). (J. Catterson Smithpresident, in 1860 .)

Lord Wrottesley (1854-58). No portrait

Sir Benjamin C. Brodie (1858-61); like Wollaston, Brodie was one of the seventeen children of a clergyman. (After G. F. Watts-Sir B. Brodie, in 1873.)

General Sir E. Sabine (1861-71). (Stephen Pearce -Mrs. Sabine.)

Sir George Airy (1871-73). No portrait.

Sir Joseph Hooker (1873-78). (Hon. John Colliersubscribers, 1881.)

William Spottiswoode (1878-June 27, 1883). (Hon. John Collier-subscribers, 1885.)

Thomas H. Huxley (July 5, 1883-85). No portrait. Sir Gabriel Stokes (1885-90). (Hubert von Herkomer-subscribers, 1891.)

Lord Kelvin (1890-95); almost whole-figure, and seated in a characteristic attitude, familiar to contemporaries. (Sir W. Q. Orchardson-subscribers, 1899.)

Lord Lister (1895-1900). Almost whole-figure. Mr. Ouless painted the masterly portrait of Darwin, etched by Paul Rajon. (Mr. W. W. Ouless (copy)purchased.)

Sir William Huggins (1900-5) ; depicted seated in presidential chair. (Hon. John Collier-subscribers, 1905.)

Lord Rayleigh (1905-8). Almost whole-figure, seated. As in the portrait of Lord Kelvin, the attitude is characteristic, and familiar to his contemporaries. (Sir George Reid--subscribers, 1903.)

Sir Archibald Geikie (1908-13). (Mr. Reginald Eve -subscribers, 1914.)

Sir William Crookes (1913-15). (Mr. E. A. Walton -subscribers.)

Sir J. J. Thomson (1915-20). (Mr. G. Fiddes Watt-subscribers, 1922.)

Sir Charles Sherrington (1920-25). Mr. Reginald Eve-subscribers, 1928.)

Lord Rutherford of Nelson (1925-30). Threequarters length, in academical robes, standing; right hand on hip, left hand resting on books below, near radium emanation apparatus. (Mr. Oswald Birleysubscribers.)

\title{
The Film in National Life
}

THE report of the inquiry conducted by the Commission on Educational and Cultural Films has just been issued under this title. It makes a substantial book of 204 pages, and is published at the very low price of $1 s$. net (London: George Allen and Unwin, Ltd.). The Commission was set up in 1929 as a result of a conference representing some hundred educational and scientific organisations. Its field of study included methods of improving films and extending their use for educational and cultural purposes ; raising the standard of public appreciation of films; and establishing a permanent central organisation for such purposes. The Commission has since received influential support, and four interim reports have been issued. Its final recommendation is "That a National Film Institute be set up in Great Britain, financed in part by public funds and incorporated under Royal Charter". It is pointed out that the chief countries of the world all possess such organisations, which vary in scope, but in no cases are concerned with censorship. An important place is assigned to the film in national life in Austria, Germany, Italy, Japan, Russia, and the United States.

The magnitude of the film industry needs no com- ment. It is estimated that there are in the world more than 60,000 cinema theatres, about half of which are wired for sound. About 85,000 people are employed by the State in the cinema industry in the U.S.S.R. alone, where the film doubtless serves as an exceedingly powerful instrument for influencing public opinion.

Films have already proved their value in medicine, in nature study and botany, in technical education, and in demonstrating industrial processes. Their application for conveying instruction on agricultural matters is specially noteworthy. Thus in the United States, films of this nature have been shown to more than twenty million farmers, and it is estimated that in Italy five to six million people saw the film entitled "The Wheat Campaign", prepared by the National Film Institute, Luce. The inestimable value of the film for recording history is evident. The official War films illustrated possibilities in this direction. Films have likewise been used in connexion with mountaineering adventures, for the study of racial subjects, and in the photomicrographic form for revealing physiological processes and for studying the growth of plant life.

No. 3268 , VoL. 129] 
At present, however, such records are made in a somewhat haphazard manner. There is no deliberate effort to collect representative records of the present age, and as yet no permanent centre where such records could be stored. The 'film library', in fact, is in its infancy. Problems of storage and the whole technique of such a library have received little study. Research has revealed that in the case of negative films taken twenty years ago, the celluloid base is gradually disintegrating. It appears that an acetate base is more stable, and positives on such a base are being made as a stand-by. Evidently this question of the permanence of films of national value is one of great importance, on which further research is needed.

A considerable portion of the report is devoted to the use of films as an educational medium in schools. The film, as a means of instruction, has certain definite advantages over oral methods. It acts as a stimulant, sharpens the critical faculty, and widens the mental horizon, and may be applied to develop dissatisfaction with the inferior and the commonplace. The quality of recollection is more vivid and the impression more lasting than when facts have been presented orally.

It is suggested that films can be applied in three chief ways: ( 1 ) in the classroom for teaching, (2) for occasional demonstrations in the school hall on subjects of general interest, and (3) in public cinema theatres, where films making a special appeal to children should be exhibited. Even in such a poor country as Austria, the use of central cinema halls, to which neighbouring schools can send contingents of children, has been developed. Another device, familiar in Italy and Russia, with which experiments have been made in England, is the travelling van.

The great difficulty is that there is at present no machinery for providing contact between university and school staffs and the producer. Many teachers are anxious to obtain educational films, and there are firms willing to make a speciality of producing them ; but firms are unwilling to enter upon production without a certainty of a market, and educational authorities are reluctant, even when funds are available, to expend money in this direction without full knowledge that the film will be really suitable for their purpose.
The report contains some data on the cost of production. A feature film, as shown publicly, may cost at least $£ 2000$ a week to make and at least $£ 3$ a foot in its final form. An educational sound film might cost between $10 \mathrm{~s}$. and $30 \mathrm{~s}$, a foot, so that a reel of $1000 \mathrm{ft}$. would cost $£ 500-£ 1500$. The production of such a film demands means of linking the expert skill of the producer and technician with the professional knowledge of the specialist and the teacher.

As regards size of film, it is believed that the $9 \mathrm{~mm}$. type is only suitable for the private cinema and for research. It is expedient to aim at the use of the $16 \mathrm{~mm}$. standard for classrooms (giving a picture $5 \mathrm{ft} . \times 6 \mathrm{ft}$. or $3 \mathrm{ft} . \times 4 \mathrm{ft}$.$) , and the full size (35 \mathrm{~mm}$.) for halls when films of general interest are shown. In an appendix to the report there is a useful list of projectors, accompanied by particulars of price, pressure, wattage and price of lamps, and other data. of the types recommended for general educational use, the $16 \mathrm{~mm}$. projector costs from $£ 15$ to $£ 80$ and the $35 \mathrm{~mm}$. from $£ 60$ to $£ 150$. The latter figure would probably have to be multiplied by four if sound production apparatus were included.

The proposed National Film Institute should serve as a positive agency to encourage valuable and good films rather than discourage bad ones. Government recognition appears essential, but the Institute might be either a Government department or institute or an incorporated institute, or a combination of both. Its functions would include acting as a national clearinghouse for information and research; assisting in the preparation of film records and serving as a national repository of films of permanent value; the stimula. tion of public opinion to demand good films ; giving advice to teachers and instructors who need films in connexion with their work ; acting as a means of liaison with trade, producers, experts, cultural interests, and educators; and encouraging research. Although the present time, when demands for economy are so imperative, is scarcely opportune for advocating the formation of a National Film Institute, it is felt that ultimately the nation would receive a more than adequate return for the expenditure involved.

\section{Jeremy Bentham, Philosopher and Social Engineer}

THE centenary of the death of Jeremy Bentham was commemorated on June 6, at University College, London, when a public lecture was delivered by Mr. C. K. Ogden on Bentham's work.

Mr. Ogden dwelt chiefly on those aspects of Bentham's work which, in his opinion, will claim the attention of future generations. His influence on the past and his message for the present were based upon his profound analysis of the symbolic factor in every branch of human activity. Bentham's exposure of word magic was motivated partly by reflections on the fear of ghosts which dominated his childhood, and partly by a dislike of legal fictions generated by Blackstone's lectures at Oxford. It was not until after his sixtieth year, however, that he embarked on the systematic development of his theory of fictions, which anticipated Vaihinger's "Philosophie des Als Ob", as well as the modern formalistic account of mathematics. It enabled him to provide a ' technological ' account of language, such as modern science demands.

Bentham's most original contribution consisted in the elaboration of a technique of 'archetypation' by means of which the fictions of physics and psycho. logy could be translated into the basic pointing symbols, which are the archetypes of all metaphor, all fictions, and all abbreviations. He himself ex- plicitly described his social and legal theories, which had so profound an effect upon the history of the nineteenth century, as applications of the principles of experimental science in the field of economics and government. From this same point of view he championed the cause of the inventor and of technical education. His younger brother, Sir Samuel Bentham, the famous marine engineer, and his nephew, George Bentham, one of the founders of systematic botany, were as much his disciples as Ricardo and Jevons in economics or Southwood Smith and Chadwick in matters of public health.

According to Bentham, all language, all symbolic forms, must be interpreted in an operational context. Some words point at things as the hands of a clock point at the hours ; others, such as 'right ', 'faculty', 'motion', ' redness', or 'of', are like single parts or accessories of a clock. They may help us to do the pointing; but any such part taken in isolation is no more than an intriguing piece of metal about which any number of conflicting theories may be held. Put it back in its place, where it helps to perform some operation, and it can be treated functionally. Above all, we can see what substitutes are possible, either for any particular part or for any portion which operates as a unit.

No. 3268, Vou. 129] 